\title{
Analisis Kualitas Soal Perlombaan Matematika Tingkat SMA
}

\author{
Abdul Karim \\ ${ }^{1}$ Program Studi Pendidikan Matematika, Fakultas Teknik, Matematika dan IPA \\ Universitas Indraprasta PGRI Jakarta \\ *E-mail: abdul.depok@gmail.com
}

\begin{abstract}
Abstrak
Tujuan dari penelitian ini adalah untuk menganalisis kualitas soal perlombaan matematika tingkat SMA sederajat berdasarkan analisis butir soal secara kuantitatif dan sebagai bahan masukan untuk perbaikan soal perlombaan matematika yang akan datang Metode penelitian yang digunakan adalah penelitian deskriptif. Dalam penelitian ini teknik menggumpulkan data adalah dokumen soal yang digunakan pada saat kompetisi matematika yang diadakan oleh program studi pendidikan matematika Universitas Indraprasta PGRI. Objek penelitian ini adalah soal (termasuk kunci jawaban) dan lembar jawaban soal yang dikerjakan peserta. Populasi dan sampel penelitian adalah seluruh soal dan jawaban pada kompetisi matematika yang berjumlah 109 peserta. Hasil analisis butir soal secara kuantitatif terbagi menjadi empat yaitu a) Ditinjau dari validitas, b) Ditinjau dari reliabilitas, c) Ditinjau dari daya beda dan 4) Ditinjau dari tingkat kesukaran.
\end{abstract}

Kata kunci: Analisis Soal, Lomba Matematika, SMA

\section{PENDAHULUAN}

Pendidikan mempunyai tugas menyiapkan sumber daya manusia untuk berinteraksi dengan lingkungannya. Senada dengan ini, Oktavia (2015) mennyatakan bahwa pendidikan dan pengajaran bertujuan untuk memberikan pengaruh dalam membentuk karakter pribadi setiap anak didik sebagai modalnya untuk berinteraksi seusia dengan norma yang berlaku di lingkungannya berada. Karakter yang baik akan membantu peserta didik dalam menghadapi tantangan global. Maka dari itu pendidikan sangat diharapkan dapat memajukan sumber daya manusia Indonesia dalam menghadapi tantangan dunia global.

Wijaya (2015) menyatakan bahwa kompetisi atau lomba merupakan suatu persaingan untuk menjadi yang terbaik, dengan adanya persaingan melalui suatu perlombaan diharapkan memiliki kemampuan dibidang tertentu dari bidang yang di lombakan. Lomba dalam hal ini adalah termasuk motivasi dari dalam dan luar, tidak dapat dipungkiri bahwa kedua motivasi tersebut memegang peranan penting dalam kegiatan proses pembelajaran. Dengan adanya lomba dapat membangkitkan nafsu belajar pada siswa dengan caramemanfaatkan sikap, cita-cita, rasa ingin tahu, dan ambisi siswa.Dengan demikian dapat kita pahami bahwa lomba atau kompetisi terdapat ambisi siswa dalam hal ini adalah ambisi untuk belajar supaya tujuan belajar dapat tercapai, yang akan menimbulkan motivasi dari siswa.

Simamora (2015) mengatakan bahwa, "Matematika merupakan hasil pemikiran manusia, menggunakan bahasa ilmiah dan alamiah atau simbol untuk menyampaikan pemikiran terhadap orang lain." Matematika pada dasarnya adalah pengetahuan yang disusun secara konsisten dan berdasarkan logika deduktif mempelajari matematika berarti berlatih mengatur dan mengarahkan jalan pemikiran yang logis.Sasaran yang pertama ditelaah oleh matematika adalah tentang bilangan dan berbagai hubungannya.Hubungan-hubungan baru tercipta setelah dilakukan empat macam pengolahan yang pokok, yaitu penjumlahan, pengurangan, perkalian dan pembagian.

Pada Jenjang SMA/SMK/MA perlombaan matematika mrupakan salah satu cabang yang sering diikut-sertakan dalam lomba tingkat nasional, bahkan tidak jarang dalam taraf internasional. Selain lomba matematika ada pula lomba sejenis seperti lomba fisika, biologi, kimia, komputer dan lain-lain. Tatacara penyelengaraannya pun tidak jauh berbeda dengan lomba lainnya, mulai dari tingkat sekolah, kabupaten/kota, propinsi, hingga tingkat nasional. Pihak yang memenagkan lomba tingkat nasional akan di undang kembali sebagai juara bertahan dalam lomba matematika tingkat nasional. 
Manfaat yang dapat di peroleh dengandiadakan lomba matematika ini dapat dilihat dari tujuan diadakan lomba matematika itu sendiri. Adapun tujuan dari lomba yang yang diharapkan sebagai berrikut:

1. Mempererat persatuan dan kesatuan bangsa melalui lomba sains dan matematika bagi generasi muda masa kini dan masa yang akan datang.

2. Menumbuhkan suasana kompetitif yang sehat dikalangan siswa menengah, baik antar sekolah, kabupaten/kota, antar provinsi, tingkat nasional, dan tingkat internasional.

3. Menjaring siswa-siswa unggul di bidang matematika, sains dan teknologi.

4. Memotivasi siswa agar menjadi terangsang untuk belajar lebih banyak tentang sains, ternyata belajar sains menyenangkan.

5. Memacu peningkatan mutu pendidikan khususnya di bidang sains bagi siswa dan warga sekolah.

Oleh karena banyak manfaat yang dapat diambil dari lomba matematika, maka seharusnya bagi pihak yang terkait seperti guru disekolah dapat membimbing siswa-siswinya jika ingin mengikuti lomba matematika tingat nasional. Persiapan yang biasa dilakukan adalah dengan cara memberikan latihan pemecahan soal kepada siswa. Informasi yang penting yang penting yang dapat didapat dari latihan pemecahan soal, tentang strukur pemecahan masalah dari masing-masing soal.

Menganalisa kualitas soal merupakan tahap yang harus ditempuhuntukmengetahui derajat kualitas suatu soal, baik soal secarakeseluruhan maupun butir soal yang menjadi bagian soal tersebut.Pada prinsipya analisis butir soal secara kuantitatif dilakukan berdasarkan kaidah penulisan soal. Aspek yang diperhatikan didalam penelaahan secara kuantitatif adalah telaah dari segi validitas, reliabilitas, daya beda dan tingkat kesukaran.

Penelaahan soal secara kuantitatif maksudnya adalah penelaahan butir soal didasarkan pada data empirik dari butir soal yang bersangkutan.Salah satu pendekatan pada analisis butir soal secara kuantitatif adalah pendekatan secara klasik. Pada pendekatan ini proses penelaahan melalui informasi dari jawaban siswa guna meningkatkan mutu butir soal yang bersangkutan. Kelebihan analisis butir soal secara klasik adalah murah, dapat dilaksanakan sehari-hari dengan cepat, sederhana, familier dan dapat mengunakan data dari beberapa peserta.Aspek yang perlu diperhatikan dalam analisis butir soal secara klasik adalah telaah dari segi validitas, reliabilitas, daya pembeda, dan tingkat kesukaran soal.

Arikunto (2010) menjelaskan bahwa "Secara garis besar ada dua macam validitas, yaitu validitas logis dan validitas empiris". Validias logis biasanya menunjukkan kondisi validsuatu instrumen berdasarkan hasil penalaran sesuai dengan persyaratan yangada.Termasuk di dalam jenis validitas logis adalah validitas isi dan validitas konstruksi (construct validity).Sedangkan yang dimaksud validitas empiris adalah penentuan valid atau tidaknya suatu instrumen berdasarkan sudah pernah diuji dari pengalaman atau belum. Terdapat empat bentuk validitas yaitu empiris, yaitu: validitas isi (content validity), validitas konstruksi (construct validity),validitas "adasekarang"(concurrentvalidity), dan validitas prediksi (predictivevalidity).

Reliabilitas merupakan penerjemahan dari kata reliability yang mempunyai asal kata rely dan ability. Pengukuran yang mempunyai reliabilitas tinggi disebut sebagai pengukuran yang reliabel. Walaupun reliabilitas mempunyai berbagainama seperti keterpercayaan, keterandalan, keajegan, kestabilan, konsistensi dan sebagainya namun ide pokok yang terkandung dalam konsep reliabilitas adalah sejauh mana hasil suatu pengukuran dapat dipercaya (Azwar, 2011).

Daya pembeda soal adalah kemampuan suatu butir soaluntuk membedakan antara siswa yang telah menguasai materi dan siswa yang belum menguasai materi yang ditanyakan. Angka yang menunjukkan besarnya daya pembeda disebut indeks daya pembeda (DP).Semakin tinggi indeks daya pembeda soal berarti semakin mampu soal yang bersangkutan membedakan siswa yang sudah memahami dan belum memahami materi. Indeks daya pembeda berkisar antara -1,00 sampai dengan $+1,00$. Semakin tinggi daya pembeda suatu soal maka semakin baik soal tersebut.Jika daya pembeda negatif berarti lebih banyak kelompok siswa yang belum memahamimaterimenjawab benar 
soal tersebut.

Tingkat kesukaran soal adalah peluang untuk menjawab benar soal pada tingkat kemampuan tertentu yang biasanya dinyatakan dalam bentuk indeks. Indeks kesukaran umumnya dinyatakan dalam bentuk proporsi yang besarnya antar 0,00 - 1,00. Semakin besar indeks kesukaran berarti semakin mudah soal tersebut dan sebaliknya.Fungsi tingkat kesukaran butir biasanya dikaitkan dengan tujuan tes. Misalnya untuk ujian akhir semester digunakan soal dengan tingkat kesukaran sedang, untuk keperluan seleksi digunakan soal dengan tingkat kesukaran tinggi, dan untukn keperluan diagnostik digunakan soal dengan tingkat kesukaran mudah.Soal yang baik adalah soal yang tidak terlalu mudah dan tidak terlalu sukar.Soal yang terlalu mudah tidak merangsang siswa untuk mempertinggi usaha pemecahannya. Sebaliknya soal yang terlalu sukar akan menyebabkan siswa menjadi putus asa dan tidak mempunyai semangat untuk mencoba lagi karena diluar jangkauannya (Arikunto, 2010).

\section{METODE/EKSPERIMEN}

Penelitian ini dilaksanakan di Universitas Indraprasta PGRI pada kegiatan lomba matematika pada tangal 19 Maret 2017. Metode penelitian yang digunakan adalah penelitian deskriptif. Penelitaian deskriptif menurut Nazil (Karim, 2017) yaitu suatu metode dalam meneliti status kelompok manusia, suatu objek, suatu kondisi, suatu sistem pemikiran ataupun suatu kelas peristiwa pada masa sekarang yang bertujuan untuk membuat deskripsi, gambaran atau lukisan secara sistematis, faktual dan akurat mengenai fakta-fakta, sifat-sifat serta hubungan antar fenomena yang diselidiki.

Populasi dan sampel penelitian adalah seluruh soal dan jawaban pada lomba matematika yang berjumlah 109 peserta.Pada penelitian ini teknik pengumpulan data yang digunakan untuk pengumpulan data memalui data dokumen yang di dapat dari hasil jawaban peserta lomba matematika yang di adakan pada tanggal 19 Maret 2017.Dalam penelitian ini dokumentasi yang digunakan oleh peneliti berupa soal dan kunci jawaban beserta lembar jawaban peserta lomba matematika. Soal lomba yang diberikan dalam bentuk pilihan ganda yang memiliki 5 obsi jawaban. Jawaban yang benar bernilai 4 dan jawaban yang salah bernilai 1 dan jawaban yang tidak terjawab bernilai 0 .

Teknik Analisis data yang digunakan secara kuantitatif dilakukan dengan mengkaji, menelaah dan menganalisis setiap soal, lalu meghitung persetasi pada setiap aspek yang diteliti. Adapun langkah-langkah dalam menganalisis data penelitian dapat diuraikan sebagai berikut:

1. Validitas

Menentukan validitas soal dengan menggunakan rumus korelasi poin biseral (Arikunto, 2008), yaitu:

$r_{p b i}=\frac{M_{p}-M_{t}}{S D_{t}} \sqrt{\frac{p}{q}}$ (Arikunto, 2008:79)

Patokan yang digunakan untuk menginterprestasi validitas (Sudijono, 2008) yaitu:

$\mathrm{R}_{\mathrm{pbi}}>\mathrm{r}_{\mathrm{t}}=$ Valid

$R_{p b i}=$ negatif $=$ invalid/tidak valid

$\mathrm{R}_{\mathrm{pbi}}<\mathrm{r}_{\mathrm{t}}=$ invalid/tidak valid

Dimana:

$r$ tabel atau $r_{t}$ pada taraf signifikansi $5 \%=0,1638$

2. Reliabilitas

Menurut Arikunto (2008) Reliabilitas adalah ketetapan suatu tes dapat diteskan pada objek yang sama untuk mengetahui ketetapan ini pada dasarnya melihat kesejajaran hasil.untuk mencari reliabilitas soal dapat dengan menggunakan rumus yang dikemukakan oleh Kuder dan 
Richardson (KR-20) menurut Sugiyono (2011), yaitu:

$$
r_{11}=\left(\frac{n}{n-1}\right)\left(\frac{S^{2}-\sum p q}{S^{2}}\right)
$$

Kriteria reliabilitas adalah sebagai berikut :

$r_{11} \leq 0,20 \quad:$ sangat rendah

$0,20<r_{11} \leq 0,40 \quad$ : rendah

$0,40<r_{11} \leq 0,60$ : cukup

$0,60<r_{11} \leq 0,80$ : tinggi

$0,80<r_{11} \leq 1,00 \quad$ : sangat tinggi

Kaidah Keputusan :

Jika $r_{11}>0,70$ (Reliabel)

Jika $r_{11}<0,70$ (Tidak Reliabel)

\section{Daya Pembeda}

Untuk menghitung daya beda, data terlebih dahulu diurutkan dari peserta yang memperoleh skor tertinggi sampai terendah. Karena banyaknya siswa dalam penelitian ini lebih dari 100 peserta, maka menurut Arikunto (2008) diambil 27\% peserta yang memperoleh nilai tertinggi (disebut kelompok atas) dan $27 \%$ peserta yang memperoleh nilai terendah (disebut kelompok bawah). Rumus untuk menentukan indeks diskriminasi menurut Sudijono (2008) adalah:

$$
P A=\frac{\sum B_{a}}{\sum J_{a}} \quad P B=\frac{\sum B_{b}}{\sum J_{b}}
$$

Kelompok atas dan kelompok bawah masing-masing diambil 29 responden.

Keterangan : Daya Beda $(D B)=P_{a}-P_{b}$

Untuk klasifikasi daya beda.

DB : Negatif : semua tidak baik

Kriteria daya pembeda soal pilihan ganda (Sudijono, 2008:389) adalah:

Tabel 1. Keriteria Daya Pembeda

\begin{tabular}{|l|l|}
\hline Nilai DB & Kriteria \\
\hline $0,00<D B \leq 0,20$ & Buruk \\
\hline $0,21<D B \leq 0,40$ & Cukup \\
\hline $0,41<D B \leq 0,70$ & Baik \\
\hline $0,71<D B \leq 1,00$ & Baik Sekali \\
\hline
\end{tabular}

4. Tingkat Kesukaran

Menurut Sudijono (2008), tingkat kesukaran instrumen dapat diuji dengan rumus:

$P=\frac{B}{J S}$

Kriteria tingkat kesukaran soal pilihan ganda Sudijono (2008)sebagai berikut;

Tabel 2. Keriteria Tingkat Kesukaran

\begin{tabular}{|l|l|}
\hline Nilai $\mathbf{P}$ & Kategori \\
\hline $0,00<P \leq 0,30$ & Sukar \\
\hline $0,31<P \leq 0,70$ & Sedang \\
\hline $0,71<P \leq 1,00$ & Mudah \\
\hline
\end{tabular}

Dalam proses penyelesaian peneliti dibantu aplikasi Ms. Excel 2010 dalam perhitungannya untuk mendapatkan persentase dan chart (diagram) yang akan ditampilkan. Persentase menurut Sudjana dan Ibrahim (2007) disetiap tingkatan melalui rumus sebagai berikut:

$P=\frac{F}{N} \times 100$

Keterangan : 
$\mathrm{P} \quad=$ Nilai persen

$\mathrm{F} \quad=$ Jumlah skor yang diperoleh

$\mathrm{N} \quad=$ Jumlah skor maksimal

\section{HASIL DAN PEMBAHASAN}

Tujuan dari hasil penelitian secara garis besar menggambarkan bagaimana analisis soal lomba matematika yang diadakan 19 Maret 2017 bertempat di kampus B, Universitas Indraprasta PGRI Jakarta. Hasil penelitian ini memaparkan deskrpsi data dan keseluruhan penelitian analisis butir soal yang terderi dari analisis soal secara kuantitatif berdasarkan validitas, reliabilitas, daya beda, dan tingkat kesukaran.

1. Karakteristik Responden

Gambaran analisis butir soal tidak terlepas dari karakteristik responden. Karakteristik responden disini dipandang dari segi jenis kelamin. Secara keseluruhan deskripsi dari karakteristik responden peserta kompetisi matematika dapat dilihat pada gambar.

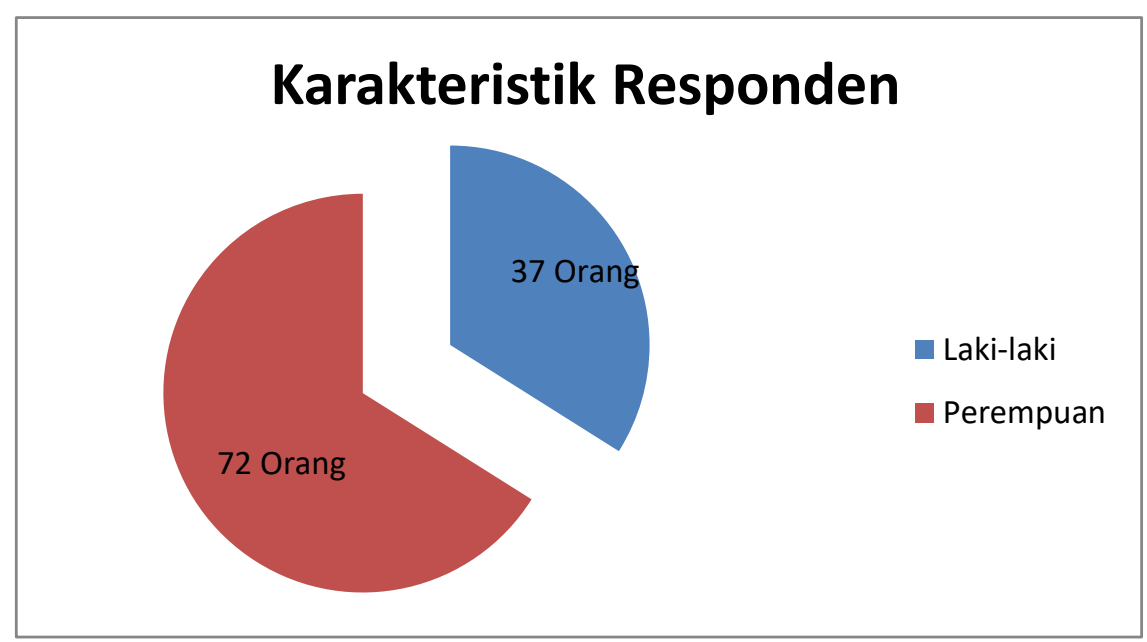

Gambar 1 Responden berdasarkan jenis kelamin

Gambar 1 menunjukkan bahawa jumlah responden berjenis kelamin perempuan sebesar 72 orang peserta atau $66 \%$, sedangkan responden yang berjenis kelamin laki-laki sebanyak 37 orang peserta atau $34 \%$.

2. Analisis butir soal secara kuantitatif yang peneliti ambil ditinjau dari validitas, daya beda, tingkat kesukaran, dan reliabilitas.

a. Analisis Butir Soal ditinjau dari Validitas 


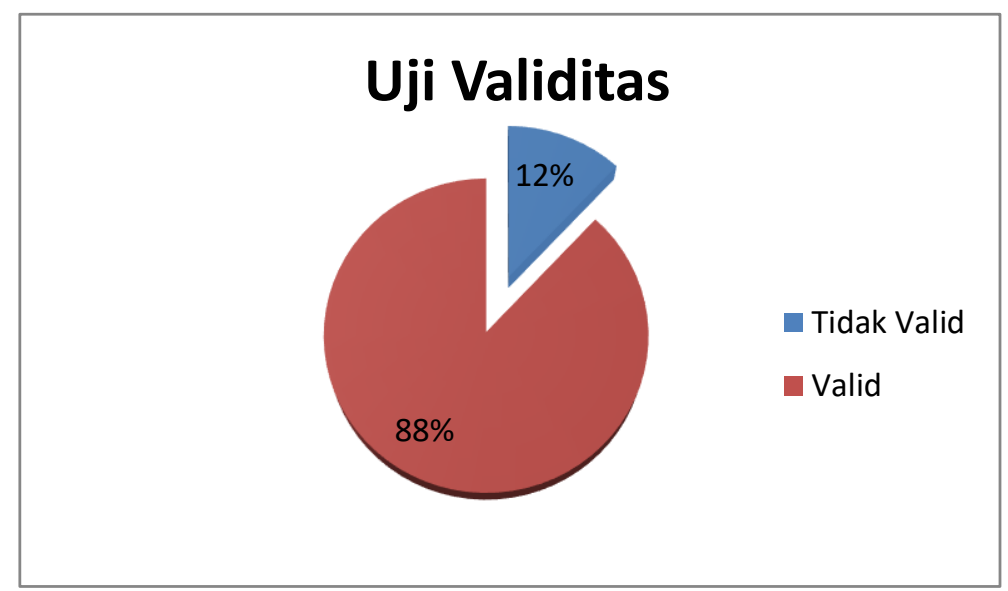

Gambar 2. Validitas

Gambar 2 analisis butir soal yang ditinjau dengan uji validitas dari 50 soal yang diberikan kepada peserta kompetisi matematika 2017 , menunjukan terdapat $12 \%$ soal yang tidak valid atau terdapat 6 soal yang terdiri nomor soal 2, 23, 27, 28, 30,dan 43 . Selanjutnya terdapat $88 \%$ soal yang valid atau terdapat 44 soal yang terdiri nomor soal 1, 3, 4, 5, 6, 7, 8, 9, 10, 11, 12, 13, $14,15,16,17,18,19,20,21,22,24,25,26,29,31,32,33,34,35,36,37,38,39,40,41,42$, $44,45,46,47,48,49,50$

b. Analisis butir Soal Ditinjau dari Daya Beda

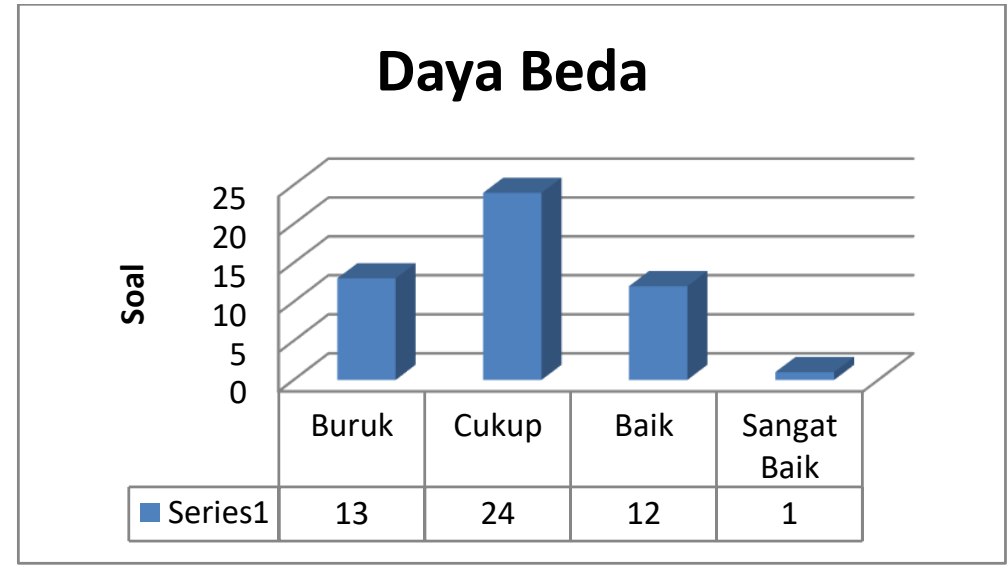

Gambar 3. Daya Beda

Dari gambar 3. untuk analisis butir soal yang ditinjau dari daya beda soal dapat dilihat dari 50 soal kompetisi matematika yang diberikan kepada peserta terdapat 13 soal yang berkeriteria buruk yaitu pada nomor soal 1, 2, 4, 12, 23, 25, 27, 28, 30, 31,39, 44, dan 45. Selanjutnya terdapat 24 soal yang berkeriteria cukup yaitu terdapat pada soal nomor $3,5,6,7,8,9,10,11$, $13,16,17,19,20,21,22,24,34,35,36,38,41,43,47$, dan 50 . Selanjutnya terdapat 12 soal yang berkeriteria baik yaitu pada nomor soal 14, 15, 18, 26, 29, 32, 33, 37, 40, 42, 46 dan 49. Selanjutnya terdapat 1 soal yang berkeriteria sangat baik yaitu terdapat pada soal 48 .

c. Analisis Butir Soal Ditinjau Dari Tingkat Kesukaran 


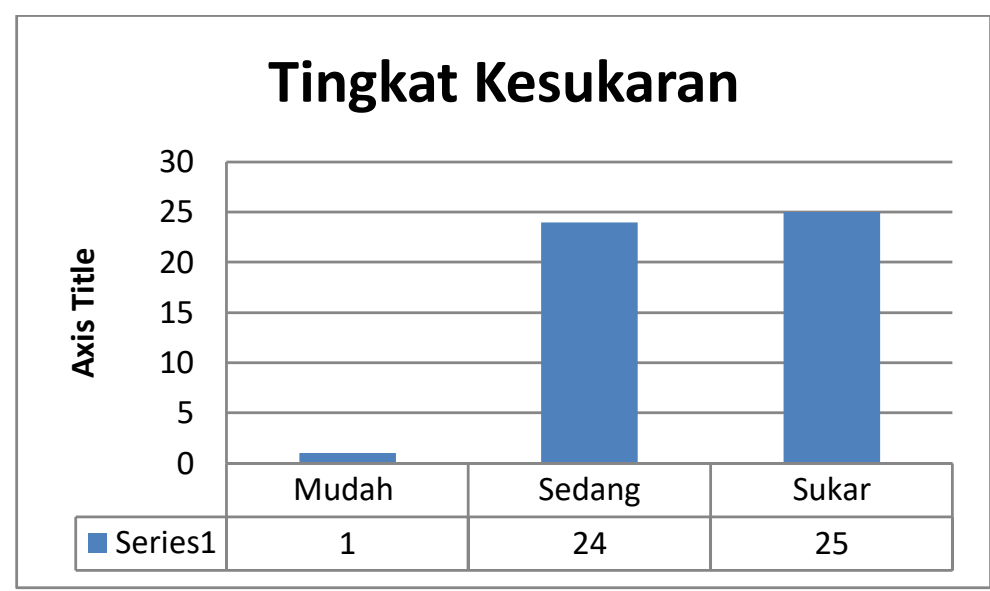

Gambar 4. Tingkat Kesukaran

Dari gambar 4 analisis butir soal yang ditinjau dari tingkat kesukaran dapat dilihat dari 50 soal kompetisi matematika terdapat satu soal yang memiliki keriteria mudah yaitu pada soal nomor 11 . Selanjutnya terdapat 24 soal yang memiliki keriteria sedang yaitu terdapat pada nomor soal 1, 5, 6, 7, 8, 14, 15, 16, 17, 18, 22, 26, 29, 31, 32, 33, 40, 42, 43, 46, 47, 48, 49, dan 50 . Selanjutnya terdapat 25 soal yang memiliki keriteria sukar yaitu terdapat pada nomor soal 2 , $3,4,9,10,12,13,19,20,21,23,24,25,27,28,30,34,35,36,37,38,39,41,44$, dan 45.

\section{d. Analisis Butir soal ditinjau dari Reliabilitas}

Analisis butir soal yang ditinjau dari aspek reliabilitas soal. Dari hasil perhitungan dengan menggunakan rumus Kuder dan Richardson (KR-20).Seluruh soal kompetsi matematika yang berjumlah 50 soal memiliki rellibilitas 0,82 . Dengan reliabilitas soal yang bernilai 0,82 ini dapat disimpulkan bahwa soal kompetisi matematika memiliki reliabiltas yang sangat tinggi.

\section{Simpulan}

\section{PENUTUP}

Analisis butir soal dalam lomba matematika sebuah proses yang sistematis yang terdiri analisis butir soal kuantitatif ditinjau dari uji validitas, dari 50 soal yang diberikan kepada peserta lomba matematika terdapat $12 \%$ atau 6 soal yang tidak valid. Analisis butir soal kunatitatif ditinjau dari daya beda, dari 50 soal kopetisi matematika tingkat daya beda soal dapat dilihat cukup baik. Analisis butir soal ditinjau dari tingkat kesukaran, dari 50 soal kompetisi matematika yang diberikan memiliki tingkat kesukaran memiliki tingkat sedang dan sukar. Analisis butir soal ditinjau dari reliabilitas, dari 50 soal kompetisi matematika memiliki reliabilitas yang sangat baik. Dengan demikian, soal lomba matematika yang diadakan oleh program studi pendidikan matematika Universitas Indraprasta PGRI sudah baik walau pun ada beberapa soal yang perlu diperbaiki.

\section{Saran}

Setelah penelitian yang telah dilakukan, peneliti merasa perlu untuk mengemukakan saransaran antara lain sebagai berikut:

a. Hendaknya soal kompetisi matematikadianalisis terlebih dahulu sebelum soal tersebut diteskan, sehingga tidak ada lagi kesalahan baik dari segi penulisan maupun bahasanya atau paling tidak bisa diminimalisir.

b. Melakukan analisi terhdap tes secara kuantitatif, sehingga dapat mengetahui sejauh mana keefektifan tes tersebut guna meningkatkan kualitas dari tes yang dibuat.

c. Dalam pembuatan soal hendaknya tidak terlalu mudah dan tidak terlalu sulit, sehingga nantinya 
dapat seimbang.

d. Setelah melakukan analisis secara kuantitatif, apabila butir-butir yang belum berfungsi dengan baik dilakukan perbaikan dan untuk butir yang sudah baik disimpan untuk bahan referensi tes yang akan datang.

\section{UCAPAN TERIMAKASIH}

Ucapan terima kasih kepada semua pihak yang dengan tulus ikhlas telah memberikan bantuan kepada peneliti dalam menyelesaikan penelitian ini terutama kepada:

1. Universitas Indraprasta PGRI yang telah memberikan tempat pelaksanaan penelitian dan sekaligus tempat pelaksanaan lomba matematika tingkat nasional.

2. Panitia lomba yang telah memeberikan dokumen-dokumen yang dibutuhkan untuk menyelesaikan penelitian ini.

\section{DAFTAR PUSTAKA}

Arikunto, S. (2010). Prosedur Penelitian Suatu Pendekatan Praktek, Jakarta: Penerbit Rineka Cipta.

Arikunto, S. (2008). Dasar-Dasar Evaluasi Pendidikan. Jakarta: Bumi Aksara.

Azwar, S. (2011). Reliabilitas dan Validitas. Yogyakarta: Pustaka Pelajar.

Karim, Abdul. (2017). Analisis Pendekatan Pembelajaran CTL (Contextual Teaching And Learning) Di SMPN 2 Teluk Jambe Timur, Karawang. Jurnal Formatif 7(2): 144-152.

Oktavia, I. (2015). Pengaruh model pembelajaran kooperatif dan kreativitas belajar siswa terhadap pemahaman konsep matematika. Jurnal Kajian Pendidikan Matematika. 1(1).

Simamora, L. (2015). Pengaruh Persepsi Siswa Tentang Kompetensi Pedagogik Guru Dan Kebiasaan Belajar Siswa Terhadap Prestasi Belajar Matematika. Formatif: Jurnal IImiah Pendidikan MIPA, 4(1).

Sudijono, A. (2008). Pengantar Evaluasi Pendidikan. Jakarta: Raja Grafino Persada.

Sudjana, A., \& Ibrahim. (2007). Penelitian dan Penilaian Pendidikan. Bandung: Sinar Baru Algensindo.

Sugiyono. (2011). Metode Penelitian Kuntitatif, Kualitatif dan R\&D. Bandung: Alfabeta. Sudjana, A., \& Ibrahim. (2007). Penelitian dan Penilaian Pendidikan. Bandung: Sinar Baru Algensindo.

Wijaya, W. A. (2015). Analisis Lomba Robotika Dalam Meningkatkan Minat Belajar Peserta Didik Sekolah Menengah Kejuruan Negeri 2 Singosari. Prosiding Seminar Nasional Fisika dan Pembelajarannya. 55-62. 